\title{
Severity of Maternal Iron Deficiency Anemia and Risk for for Low Birth Weight Babies
}

\section{Al Hassan Gamal Gomaa ${ }^{1 *}$ MSc; Mohamed Ali Mohamed ${ }^{1}$ MD; Mohamed Saad Eldein Radwan ${ }^{2}$ MD ;} Ahmed Mohamed El Sheikh ${ }^{1}$ MD

\section{*Corresponding Author: \\ Al Hassan Gamal Gomaa hasan.azrak40@gmail.com}

Received for publication january 14 2021; Accepted january 31, 2021; Published online january 31, 2021.

Copyright 2021 The Authors published by Al-Azhar University, Faculty of Medicine, Cairo, Egypt. All rights reserved. This an openaccess article distributed under the legal terms, where it is permissible to download and share the work provided it is properly cited. The work cannot be changed in anyway or used commercially.

doi: 10.21608/aimj.2021.57248.1405

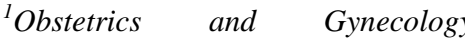

Department, Faculty of Medicine, Al-Azhar University, Cairo,Egypt.

${ }^{2}$ Clinical Pathology Department, Faculty of Medicine, Al-Azhar University, Cairo,Egypt

\begin{abstract}
Background: Anemia is one of the most prevalent diseases in the world affecting all ages and races of patients. Root causes and prevalence vary by age group and socio-economic state.

Aim of the work: is to evaluate maternal Iron deficiency anemia before birth and to know its effect on fetal weight at birth.

Patients and Methods: This is a cross-sectional study which included 500 pregnant females who had presented and admitted to Obstetrics and Gynecology Department of Bab Alseheiria University Hospital at the time of delivery.

Results: Birth weight ranged from 1850 to $3500 \mathrm{gm}$ with mean $2593.192 \mathrm{gm}$. Thirty six percent $(36 \%)$ had fetuses with . Hemoglobin level ranged from 6.5 to $10.9 \mathrm{~g} / \mathrm{dL}$ with mean $9.258 \mathrm{~g} / \mathrm{dL}$. Forty-five $(45 \%)$ had moderate anemia, while $22.6 \%$ had severe anemia. There are statistically non- $\mathrm{s}$ between mild, moderate and severe anemic groups regarding age, gravidity, parity, history of abortion and mode of delivery. Conclusion: Maternal anemia is associated with low birth weight . Also, anaemia in pregnancy is still a major health problem. The improvements achieved in the developed world may largely be due to more effective diagnosis and treatment.
\end{abstract}

Keywords: Iron Deficiency;Low Birth;Weight.

\section{INTRODUCTION}

Anemia is one of the most common disorders in the world and affects patients of all ages and races. The underlying causes and prevalence vary according to age group and socio-economic background, but pregnant women everywhere are highly vulnerable to developing anemia, and the vast majority of cases are attributable to iron deficiency. ${ }^{1}$ Iron deficiency is the most common nutritional disorder and the main cause of anemia during pregnancy. Published research shows that maternal iron deficiency affects the health of the mother and the baby, and is also likely responsible for decreased uterine growth, premature births, and cognition. Weakness and lack of nutrition. ${ }^{2}$ Babies whose birth weight is less than 2,500 grams are known to be infants, regardless of gestational age. The extent to which maternal hemoglobin affects fetal weight remains uncertain. Some studies showed a strong association between low prenatal hemoglobin, while others did not find a significant association. ${ }^{3}$ Therefore, the aim of this study is to evaluate maternal Iron deficiency anemia before birth and to know its effect on the weight of the fetus at birth.

\section{PATIENTS AND METHODS}

This is a cross-sectional study which included 500 pregnant females who had presented and admitted to Obstetrics and Gynecology Department of Bab Alseheiria University Hospital at the time of delivery.

The study group was anemic pregnant females according to WHO definition of anemia with pregnancy which is hemoglobin level below 11 $\mathrm{gm} \%$.

Inclusion criteria: Singleton, viable pregnancy. Accurate dates Last Menstrual Period (LMP). deficiency anemia: Hb level less than $11 \mathrm{~g} \%$. Serum iron $<7.1 \mu \mathrm{g} / \mathrm{l}$. Serum ferritin $<30 \mathrm{ng} / \mathrm{l}$. Total iron binding capacity $>13.1 \mu \mathrm{mol}$. BMI $>19$.

Exclusion criteria: Women with multiple pregnancies. Pregnancy duration was less than 37 weeks of gestation. Associated medical maternal complications, which may affect fetal birth weight e.g. diabetes, hypertension and cardiac diseases. History of antiphospholipid syndrome. BMI $<19$. 


\section{Methods:}

Verbal and written informed consent was taken before the start of study. The group of study was evaluated for data collection through: Full history obstetric and gynecological history. Examination finding and exclusion of medical disorders. $\mathrm{Hb}$ level measurement before delivery. Assessment of fetal outcome birth weight. Serum ferritin. Serum iron. Total iron binding capacity.

Data collection:

Mother's age and risk( primigravida )They are the females who have never become pregnant, the midwives who have given birth two or three times before are chosen, and the Grand Multara who have given birth five or more times before are chosen. Gestational age (calculated using Nigel's formula).

\section{RESULTS}

About $26 \%$ were primigravida, $26.4 \%$ were nullipara and $87 \%$ had no history of abortion. Gravidity ranged from 1 to 6 with median 3. Parity ranged from 0 to 5 with median 2. Abortion ranged from 0 to 3 with median 0 . Forty percent $(40 \%)$ delivered via CS.

\begin{tabular}{|c|c|}
\hline Parameter & $\mathbf{N}=500(\%)$ \\
\hline Gravidity: & \\
Median & 3 \\
Range & $1-6$ \\
Primigravida & $129(25.8 \%)$ \\
$2-3$ & $284(56.8 \%)$ \\
$4-6$ & $87(17.4 \%)$ \\
\hline Parity: & \\
Median & 2 \\
Range & $0-5$ \\
Nullipara & $132(26.4 \%)$ \\
$2-3$ & $307(61.4 \%)$ \\
$4-5$ & $61(12.2 \%)$ \\
\hline Abortion: & \\
Median & 0 \\
Range & $0-3$ \\
0 & $435(87 \%)$ \\
$1-2$ & $63(12.6 \%)$ \\
3 & $2(0.4 \%)$ \\
\hline Mode of delivery: & $300(60 \%)$ \\
VD & $200(40 \%)$ \\
CS &
\end{tabular}

Table 1: Distribution regarding obstetric history: Birth weight ranged from 1850 to $3500 \mathrm{gm}$ with mean $2593.192 \mathrm{gm}$. Hemoglobin level ranged from 6.5 to $10.9 \mathrm{~g} / \mathrm{dL}$ with mean $9.258 \mathrm{~g} / \mathrm{dL}$.

\begin{tabular}{|c|c|}
\hline Parameter & $\mathrm{N}=500(\%)$ \\
\hline Birth weight (gram): & \\
Mean \pm SD & $2593.192 \pm 420.063$ \\
Range & $1850-3500$ \\
\hline Hemoglobin: & \\
Mean \pm SD & $9.268 \pm 1.189$ \\
Range & $6.5-10.9$ \\
\hline
\end{tabular}

Table 2: Birth weight and hemoglobin level among the studied patients:

Thirty six percent (36\%) had fetuses with Forty-five $(45 \%)$ had moderate anemia, while $22.6 \%$ had severe anemia.

\begin{tabular}{|c|c|}
\hline Parameter & $\mathrm{N}=500(\%)$ \\
\hline Birth weight: & \\
& $180(36)$ \\
Normal birth weight & $320(64)$ \\
\hline
\end{tabular}

Table 3: Distribution regarding occurrence of :

There is statistically non- between the studied groups (with various degrees of anemia severity) regarding gravidity, parity, history of abortion or mode of delivery.

\begin{tabular}{|c|c|c|}
\hline Severity & $\mathrm{N}=250$ & $\%$ \\
\hline Mild $(10-<11 \mathrm{~g} / \mathrm{dL})$ & 162 & 32.4 \\
Moderate $(8-<10 \mathrm{~g} / \mathrm{dL})$ & 225 & 45 \\
Severe $(<8 \mathrm{~g} / \mathrm{dL})$ & 113 & 22.6 \\
\hline
\end{tabular}

Table 4: Distribution of the studied anemic patients according to severity of anemia:

Studied groups (with various degrees of anemia severity) regarding occurrence of . On LSD comparison, the difference is significant between each two groups (LBW prevailed in $73.5 \%$ within severe group while it occurred in $11.1 \%$ within mild group)

\begin{tabular}{|c|c|c|c|c|c|}
\hline \multirow{3}{*}{$\begin{array}{l}\text { Mode of } \\
\text { delivery }\end{array}$} & \multicolumn{3}{|c|}{ Severity } & \multicolumn{2}{|c|}{ Test } \\
\hline & Mild & $\begin{array}{l}\text { Moderat } \\
\text { e }\end{array}$ & $\begin{array}{c}\text { Sever } \\
\text { e }\end{array}$ & \multirow{2}{*}{$\mathbf{K W} / \chi$} & \multirow[b]{2}{*}{$\mathbf{p}$} \\
\hline & $\begin{array}{c}N=16 \\
2\end{array}$ & $N=225$ & $\begin{array}{c}N=11 \\
3\end{array}$ & & \\
\hline $\begin{array}{c}\text { Gravidit } \\
\text { y: } \\
\text { Median } \\
\text { Range }\end{array}$ & $\stackrel{2}{1-6}$ & $\stackrel{2}{1-6}$ & $\begin{array}{c}3 \\
1-6\end{array}$ & 4.589 & $\begin{array}{c}0.10 \\
1\end{array}$ \\
\hline $\begin{array}{l}\text { Parity: } \\
\text { Median } \\
\text { Range }\end{array}$ & $\begin{array}{c}2 \\
0-5\end{array}$ & $\begin{array}{c}1 \\
0-5\end{array}$ & $\begin{array}{c}2 \\
0-5\end{array}$ & 5.814 & $\begin{array}{c}0.05 \\
5\end{array}$ \\
\hline $\begin{array}{c}\text { Abortion } \\
\text { : } \\
\text { Median } \\
\text { Range }\end{array}$ & $\begin{array}{c}0 \\
0-2\end{array}$ & $\begin{array}{c}0 \\
0-3\end{array}$ & $\begin{array}{c}0 \\
0-2\end{array}$ & 0.098 & $\begin{array}{c}0.95 \\
2\end{array}$ \\
\hline $\begin{array}{c}\text { Mode of } \\
\text { delivery } \\
\text { Vaginal } \\
\text { delivery } \\
\text { CS }\end{array}$ & $\begin{array}{c}107 \\
(66) \\
55 \\
(44)\end{array}$ & $\begin{array}{c}130 \\
(57.8) \\
95(42.2)\end{array}$ & $\begin{array}{c}63 \\
(55.8) \\
50 \\
(44.2)\end{array}$ & 3.783 & $\begin{array}{c}0.15 \\
1\end{array}$ \\
\hline
\end{tabular}

Table 5: Relation between obstetric history, mode of delivery and anemia severity:

\begin{tabular}{|c|c|c|c|c|c|}
\hline \multirow{2}{*}{$\begin{array}{c}\text { Birth } \\
\text { weig }\end{array}$} & \multicolumn{3}{|c|}{ Severity } & \multicolumn{2}{|c|}{ Test } \\
\cline { 2 - 5 } ht & Mild & $\begin{array}{c}\text { Moder } \\
\text { ate }\end{array}$ & Severe & \multirow{2}{*}{$\chi^{2}$} & \multirow{2}{*}{$p$} \\
\cline { 2 - 4 } & $\mathrm{N}=162$ & $\mathrm{~N}=225$ & $\mathrm{~N}=113$ & & \\
\hline LBW & 18 & 79 & 83 & & \\
Nor & $(11.1)$ & $(35.1)$ & $(73.5)$ & 10 & $<0.00$ \\
mal & 144 & 146 & 30 & 9.5 & $1^{* *}$ \\
\hline $\mathrm{P}$ & $(88.9)$ & $(64.9)$ & $(26.5)$ & & \\
$\left(\chi^{2}\right)$ & $01^{* *}$ & $01^{* *}$ & $01^{* *}$ & & \\
\hline
\end{tabular}

Table 6: Relation between birth weight and anemia severity: 


\section{DISCUSSION}

Around $7-15 \%$ of all live births per year worldwide are of , a pregnancy result that is a significant public health concern that is more common in countries with less financial resources. ${ }^{4}$ There is a greater chance of child mortality and morbidity for babies born with a weight of less than 2,500 grams. can be favoured by hormonal, social, environmental variables and insufficient lifestyle, either before or during pregnancy. Some dietary factors, such as a diet that is deficient in nutrients and inadequate weight gain during pregnancy, lead to a reduction in nutrient intake that is necessary for fetal development.such as B vitamins and iron. .

Ionic iron is the mineral that encourages fresh hemoglobin production and is the primary source of transfer of energy and oxygen to the organs of the body. (6) At any point of pregnancy and $<100 \mathrm{G} / 1$ after birth, the World Health Organisation describes anemia as hemoglobin(Hb)Less than $110 \mathrm{~g} / \mathrm{L}$. (1) In the second trimester of pregnancy, biochemical changes arise, resulting in increased plasma volume along with less rise in red cell mass, resulting in blood thinning known as "physiological anemia." Thus, in the second trimester, a threshold $\mathrm{Hb}<105$ $\mathrm{G} / \mathrm{l}$ is commonly used in all international standards for assessing and directing treatment ${ }^{7}$

It is anemia caused by iron deficiency (IDA). Roughly 50 percent of cases are worldwide. In terms of iron status, it is necessary to remember that with reduced iron reserves, a significant number of women start pregnancy. In the United States, iron stores are robbed of more than a third of women of childbearing age. At the onset of birth, CRI is 3.8 times more common in pregnant women, which confirms the hypothesis of reduced iron reserves before conception. ${ }^{8}$

Brannon and Taylor estimated ${ }^{6} 18$ percent of IDA distributed among women who are pregnant with hemoglobin levels lower than $115 \mathrm{~g} / \mathrm{L}$ and ferritin levels lower than $<12 \mathrm{Ng} / \mathrm{ml}$ increased by 19.6 percent, identified as $<12 \mathrm{Ng} / \mathrm{ml}$.

in infancy and adolescence is a significant determinant of death, morbidity and injury and has a long-term health effect in adult life. In babies with a (LBW), newborns are 20 times more likely to die than larger babies (about $2.5 \mathrm{Kg}$ ) worldwide. It has also been found to be a significant neonatal morbidity risk factor. There are two results, namely short gestational age (premature birth) and limited gestational age, presumably representing a group LBW (childbirth of eight babies less than $2.5 \mathrm{~kg}$ ) (SGA). ${ }^{10}$

Regarding the obstetric history of the group studied in this study, approximately $26 \%$ were virologists, $26.4 \%$ were drug-dependent and $87 \%$ had no history of miscarriage.. Gravity ranged from 1 to 6 with an average 3. It ranged from parity from 0 to 5 with an average 2 . Ranging abortion $\mathrm{Z}$ from 0 to 3 average 0 .
In our study, forty percent (40\%) were delivered via computer science. Terefe et al.compare 13 Hematological features and iron status in newborns from mothers with various anemia and found that most babies were born via vaginal delivery (78.7\%).

In our study ranged from birth weight for patients undergoing a study from 1850 to 3500 grams with an average 2593.192 grams. Thirty-six percent $(36 \%)$ had fetuses with. Terefe et al.is found ${ }^{13}$ The children had an average weight 3,100 grams and was the number of a few of them low weight when childbirth Dah .

In our study, ranged hemoglobin level from 6.5 to $10.9 \mathrm{~g} /$ $\mathrm{dl}$ an average of $9.258 \mathrm{~g} / \mathrm{dl}$. Terefe et al.is found ${ }^{13} \mathrm{The}$ average level of hemoglobin mothers was $12.2 \mathrm{~g} / \mathrm{dl}$.

In our study, the 45 patients study subjects $(45 \%)$ suffer from anemia average, while it was $22.6 \%$ suffer from anemia blood acute. There are statistically $\mathrm{s}$ is statistically significant between the groups of blood anemia mild, medium and severe with regard to age and gravity, and Altec Equal and history of abortion and the method of birth .

Color et al. ${ }^{14}$ In the anemic population, the probability of reduced birth weight was 1.9 times greater. ${ }^{14}$ Jones et al. ${ }^{15}$ In anemic mothers, a rise in the occurrence of was also found, but the difference from the non-anemic population was marginal.

Terefe et al. ${ }^{13}$ Cohort mothers with low levels of hemoglobin $(<11 \mathrm{~g} / \mathrm{dL})$ under IDA. Mothers with average levels of hemoglobin $(11 \mathrm{~g} / \mathrm{dL})$ were graded as: NA. 21 mothers (23.6 percent) were then classified as IDA Bloody, while the remaining 68 mothers (76.4 percent) are in the NA. They concluded that IDA Maternal may have an effect on the baby's iron reserves

\section{CONCLUSION}

This research revealed that iron deficiency anemia in pregnant women is a reasonably common disease. High risk factors are low socioeconomic status, various groups, and old maternal age, and should be taken into account. These reports showed that as a prevention measure, intensive monitoring and supplementation in high-risk pregnancies should be assessed. The latest studies show that is linked with maternal anemia. Anemia still remains a significant health concern during breastfeeding. Improvements made in the developing world can be partly due to more successful care and diagnosis..

\section{REFERENCES}

1- WHO (2015): The Global Prevalence of Anaemia in 2011. World Health Organization.

2- Haider BA, Olofin I, Wang M, Spiegelman D, Ezzati M, Fawzi WW : Anaemia, prenatal iron use, and risk of adverse pregnancy outcomes: systematic review and meta-analysis. BMJ.2013; 346:f3443.

3- Kaufman S: Effect of 5x-pregnant-3a-ol-20-one on nitric oxide biosynthesis and plasma volume in rots. Am J Physiol. 2008; 280: 1902. 
4- UNICEF (): Low Birthweight: Country, Regional and Global Estimates.2004; UNICEF: New York, NY, USA.

5- Bird AL, Grant CC, Bandara DK, Mohal J, AtatoaCarr PE, Wise MR, Inskip H, Miyahara M, Morton SM: Maternal health in pregnancy and associations with adverse birth outcomes: Evidence from growing up in New Zealand. Aust. N. Z. J. Obstet. Gynaecol. 2017; 57: 16-24.

6- Brannon PM and Taylor CL: Iron supplementation during pregnancy and infancy: Uncertainties and implications for research and policy. Nutrients.2017; 9(12): 1327.

7- Wassef A, Nguyen QD, St-André M: Anaemia and depletion of iron stores as risk factors for postpartum depression: A literature review. J Psychosom Obstet Gynaecol.2018; 1-10.

8- Banjari I: Iron Deficiency Anemia and Pregnancy. Current Topics in Anemia.2018; 73.

9- Stangret A, Wnuk A, Szewczyk G, Pyzlak M, Szukiewicz D: Maternal hemoglobin concentration and hematocrit values may affect fetus development by influencing placental angiogenesis. J. Matern. Fetal Neonatal Med.2017; 30: 199-204.

10- Ticconi C, Mapfumo M, Dorrucci M, Naha N, Tarira E, Pietropolli A, et al.: Effect of maternal HIV and malaria infection on pregnancy and perinatal outcome in Zimbabwe. $J$ Acquir Immune Defic Syndr.2005; 34: 289-94.
11- Ahmad MO, Kalsoom U, Sughra U, Hadi U and Imran M: Effect of maternal anaemia on birth weight. J Ayub Med Coll Abbottabad.2011; 23(1).

12- Ajepe AA, Okunade KS, Sekumade AI, Daramola ES, Beke MO, Ijasan O, et al.: Prevalence and foetomaternal effects of iron deficiency anaemia among pregnant women in Lagos, Nigeria. Plos One .2020; 15(1): e0227965.

13-Terefe B, Birhanu A, Nigussie P and Tsegaye A: Effect of maternal iron deficiency anemia on the iron store of newborns in Ethiopia. Anemia.2015; Article ID 808204.

14-Lone FW, Qureshi RN, Emanual F: Maternal anaemia and its impact on perinatal outcome in a tertiary care hospital in Pakistan. Trop Med Int Health.2004; 4: 486-9.

15- Jones DW, Weiss HA, Changalucha JM, Todd J, Gumodoka B, Bulmer J, et al : Adverse birth outcomes in United Republic of Tanzania: Impact and prevention of maternal risk factors. Bull World Health Organ.2007; 85: 9-18.

16- Badshah S, Mason L, Mckelvie K, Payne R, Lisboa PJ: Risk factors for in the public hospitals at Peshawar, NWFP-Pakistan. BMC Public Health.2008; 8: 197-206.

17- Mavalankar DV, Gray RH, Trivedi CR: Risk factors for preterm and term in Ahmedabad, India. Int $J$ Epidemiol.1992; 21: 263-72.
Obstetrics and

Gynecology 